\title{
DEVELOPING A CHRONOLOGY INTEGRATING ARCHAEOLOGICAL AND ENVI- RONMENTAL DATA FROM DIFFERENT CONTEXTS: THE LATE HOLOCENE SEQUENCE OF OUNJOUGOU (MALI)
}

\author{
Sylvain Ozainne ${ }^{1,2} \cdot$ Laurent Lespez $^{3} \cdot$ Yann Le Drezen ${ }^{3,4} \cdot$ Barbara Eichhorn $^{5} \bullet$ \\ Katharina Neumann ${ }^{5}$ Eric Huysecom ${ }^{1}$
}

\begin{abstract}
At Ounjougou, a site complex situated in the Yamé River valley on the Bandiagara Plateau (Dogon country, Mali), multidisciplinary research has revealed a rich archaeological and paleoenvironmental sequence used to reconstruct the history of human-environment interactions, especially during the Late Holocene (3500-300 cal BC). Geomorphological, archaeological, and archaeobotanical data coming from different sites and contexts were combined in order to elaborate a chronocultural and environmental model for this period. Bayesian analysis of $54{ }^{14} \mathrm{C}$ dates included within the general Late Holocene stratigraphy of Ounjougou provides better accuracy for limits of the main chronological units, as well as for some particularly important events, like the onset of agriculture in the region. The scenario that can be proposed in the current state of research shows an increasing role of anthropogenic fires from the 3rd millennium cal BC onwards, and the appearance of food production during the 2 nd millennium cal $\mathrm{BC}$, coupled with a distinctive cultural break. The Late Holocene sequence ends around $300 \mathrm{cal} \mathrm{BC}$ with an important sedimentary hiatus that lasts until the end of the 4th century cal AD.
\end{abstract}

\section{INTRODUCTION}

The Late Holocene is considered a key period of cultural as well as environmental change in subSaharan West Africa (McIntosh 2006). Important cultural innovations were the gradual spread of cattle breeding long after Early Holocene beginnings in the eastern Sahara (Marshall and Hildebrand 2002; Jousse 2006), the emergence of agriculture (Kahlheber and Neumann 2007), and finally of metalworking (Huysecom 2001; Killick 2004; McIntosh 2006). They were accompanied by climatic oscillations within the frame of a general, severe aridification trend (McIntosh 2006).

However, research on the West African environmental and cultural history during that period is still scarce, particularly because sites allowing for the establishment of a precise chronostratigraphy and for reconstructing the history of human-environment relationships are rare. Understanding environmental changes appears crucial to explain the relationships between the settlement patterns, landuse strategies, and the available natural resources (McIntosh et al. 2000; Mayor et al. 2005). Environmental changes may strongly influence settlement patterns and even force dramatic shifting of occupation, as evidenced for the more arid African regions during the Holocene (Kuper and Kröpelin 2006). From 1997 onwards, research at the Ounjougou site complex, located in the Yamé River valley on the plateau of Bandiagara, has aimed to establish a chronocultural and paleoenvironmental sequence for the Dogon country, Mali (Figure 1). Discovered in the early 1990s, the complex was revealed by a 10-m-deep incision of the Yamé River, due to a huge flood flow during the rainy season of 1936, which led to fast regressive erosion (Rasse et al. 2006). The importance of this site complex lies in a very long-term archaeological sequence, reaching from the Middle Pleistocene to the recent Dogon occupations. Its rich and complex Holocene sequence (Rasse et al. 2006; Lespez et al. 2008) is characterized by an exceptional preservation of macro- and microbotanical remains, allowing a precise study of human-environment interactions during the Late Holocene period

\footnotetext{
${ }^{1}$ Department of Anthropology and Ecology, University of Geneva, 1211 Genève 4, Switzerland.

${ }^{2}$ Corresponding author. Email: sylvain.ozainne@unige.ch.

${ }^{3}$ Department of Geography, GEOPHEN, University of Caen-Basse Normandie-UMR 6554 CNRS LETG, 14032 Caen, France.

${ }^{4}$ LEESA Laboratory, University of Angers, 49045 Angers Cedex, France.

${ }^{5}$ Goethe University Frankfurt, Institut für Archäologische Wissenschaften, 60323 Frankfurt, Germany.
}

(C) 2009 by the Arizona Board of Regents on behalf of the University of Arizona

Proceedings of the 5th International ${ }^{14} \mathrm{C}$ and Archaeology Symposium, edited by Irka Hajdas et al.

RADIOCARBON, Vol 51, Nr 2, 2009, p 457-470 


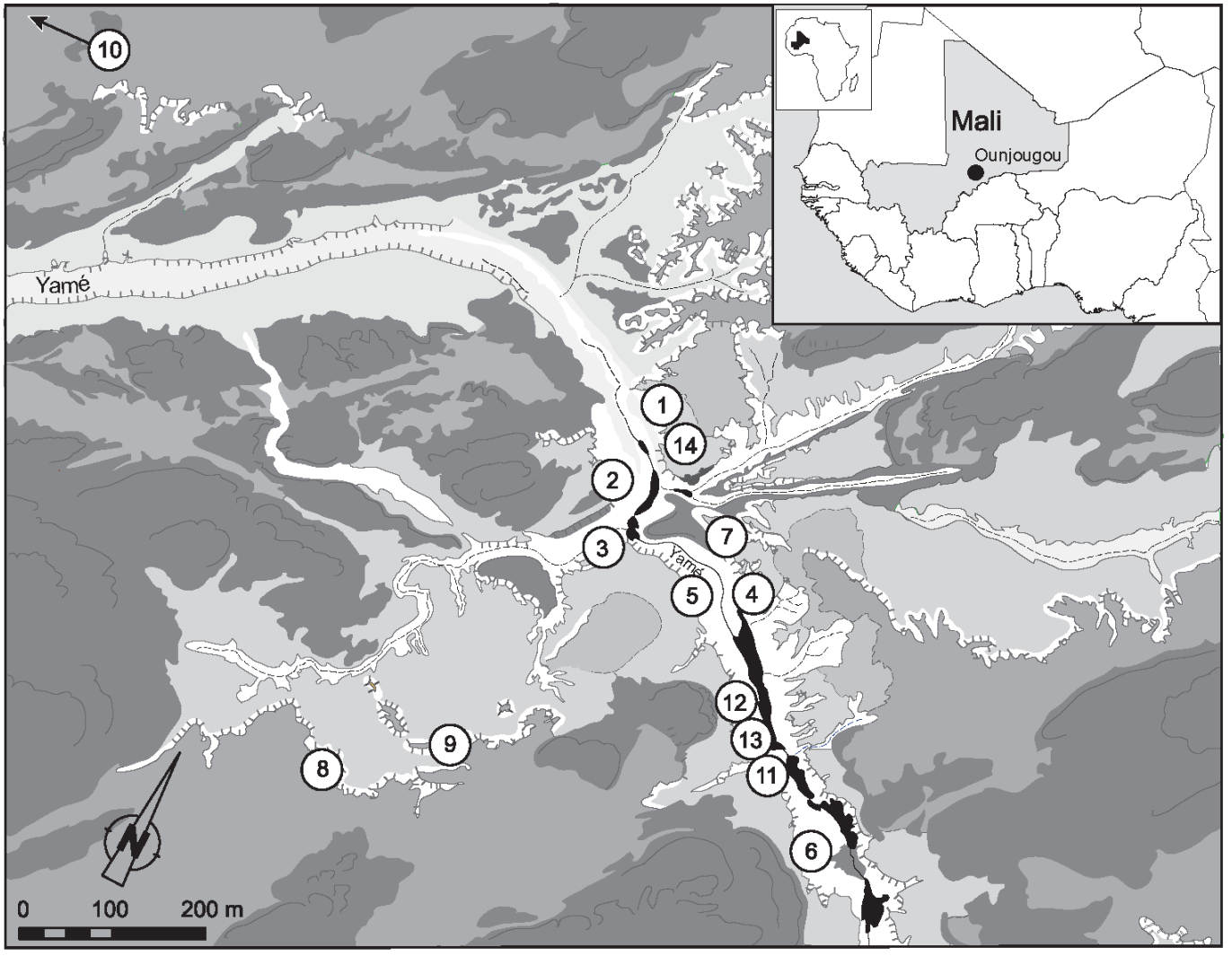

Legend
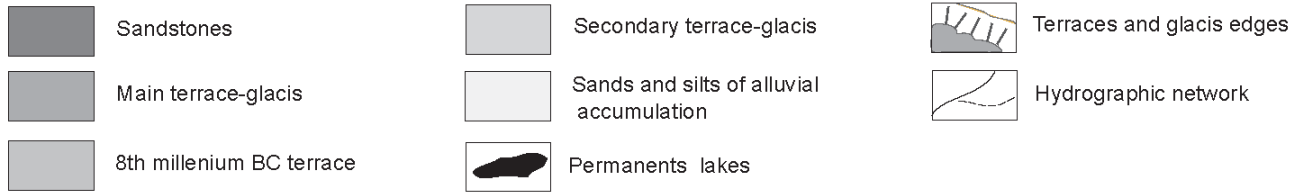

Figure 1 Location of Ounjougou site complex, with detailed position along the Yamé Valley of the sites mentioned in the text. Site numbers refer to the "Map" columns in Tables 1 and 2. Cartography by M Rasse (Huysecom et al. 2002), modified.

(3500-300 cal BC; Le Drezen 2008). The site's geographical position at the current boundary between the Sudanian and the Sahelian zone is well suited to document precisely climatic and related floristic fluctuations and possible shifts of vegetation zones. The limits of the Sudanian and Sahelian climatic zones are defined by the prevailing latitudinal precipitation gradient, which is due to the gradual northward migration of the ITCZ (Intertropical Convergence Zone), accompanied by moist tropical monsoon circulation during the rainy season (Nouaceur 2001; Kröpelin et al. 2008: Figure 1). The distribution of vegetation units and of important floristic elements in the research area is mainly confined to these climatic features (Granier 2001) and reflected their fluctuations in the past (Eichhorn and Neumann, in press). As the prehistoric settlement, land use, and environment history of the Dogon plateau was totally unknown until recently, and remained incomplete for the protohistoric and historic phases (Huysecom et al. 2004; Mayor et al. 2005), the Ounjougou site complex is of significant importance for its reconstruction and motivated the creation of the multidisciplinary project "Human Settlement and Palaeoclimatic Evolution in West Africa" in 1997 
(Huysecom 2002). Today, 14 institutions and laboratories in Switzerland, Mali, France, and Germany collaborate in this project (Huysecom and Sanogo 2006). In order to establish a general chronocultural and paleoenvironmental model for the Ounjougou region, archaeological, archaeobotanical, and chronological data coming from different kinds of sites and contexts had to be combined. Indeed, archaeological layers at Ounjougou are in some cases interstratified in the complex fluviolacustrine sedimentation of the Yamé River, but are also often found on the surrounding plateau in a less precise stratigraphic context, disrupted by many pedological features. Beyond the reconstruction of cultural patterns, archaeological data were used to set up some accurate links between these different stratigraphic sequences. Using Bayesian analysis, an overall sequence, including stratigraphical and chronological data from all environmental and archaeological sites of the valley and the plateau, was subsequently constructed. In addition, data on Late Holocene paleovegetation and fire history (Eichhorn and Le Drezen 2006; Le Drezen 2008; Eichhorn and Neumann, in press) were included. The resulting structure defines general chronological units, and provides us with a tool to analyze the evolution of cultures, landscapes, and human-environment interactions and discuss the results obtained at Ounjougou in comparison with recent paleoenvironmental studies available, with an emphasis on the impact of agriculture onset in sub-Saharan West Africa.

\section{METHODS}

With the aim to establish a comprehensive Late Holocene sequence for Ounjougou, a combined approach was developed, comprising a geomorphological and chronostratigraphic study of the Yamé Valley as well as archaeological and archaeobotanical studies. This combination allowed us to reconstruct the evolution of both the Late Holocene cultural and environmental context. While developing this general sequence, the main methodological difficulty was to combine paleoenvironmental, archaeological, and chronological data coming from different contexts and from many sites distributed over a vast area (Figure 1; Tables 1-2). It was particularly necessary to establish connections between sites included in the complex fluvio-lacustrine sedimentation of the Yamé River and sites located in a colluvio-alluvial context on the surrounding plateau. Vegetation and landscape reconstructions were elaborated by means of palynological and anthracological studies (Le Drezen 2008; Lespez et al. 2008; Eichhorn and Neumann, in press). An analysis of the signature of burning events, comprising morphological and reflectance studies of charcoal particles, was also realized in order to characterize the fire regime on a fine scale, down to the season (Le Drezen 2008). The main paleoenvironmental data are included in the scenario in the Discussion chapter, but technical aspects and details concerning environmental studies are not presented in this paper, as they are the object of specialized articles in press (Eichhorn and Neumann, in press) or in preparation.

\section{Archaeological Investigations}

From the beginning of the project onwards, archaeological investigations concerning the Late Holocene were carried out in several steps. General surveys conducted between 1994 and 2002 all along the Yamé River valley and on the surrounding plateau, including the realization of dozens of test pits and profiles, led to the discovery of 6 major archaeological sites related to this period. Larger excavations were conducted on sites with a sufficient sedimentation and a high potential to discover artifacts in a good stratigraphic context. Typo-technical and stratigraphical analyses of artifacts were conducted, essentially focusing on ceramic features like decoration patterns, morphology, and paste composition. Beyond the reconstruction of cultural assemblages, archaeological studies allowed us to identify clear archaeological horizons, and were useful to set up accurate links between the valley and the plateau sequences. Between 1997 and 2001, a first chronocultural sequence including 5 major phases was elaborated to reconstruct an overall Holocene settlement 
Table 1 Chronostratigraphic and spatial attribution of the HR1 unit ${ }^{14} \mathrm{C}$ dates, with calibrations, highest posterior densities and agreement indices (A). Material (M): $\mathrm{C}=$ Charcoal; $\mathrm{P}=$ Pearl millet caryopsis.

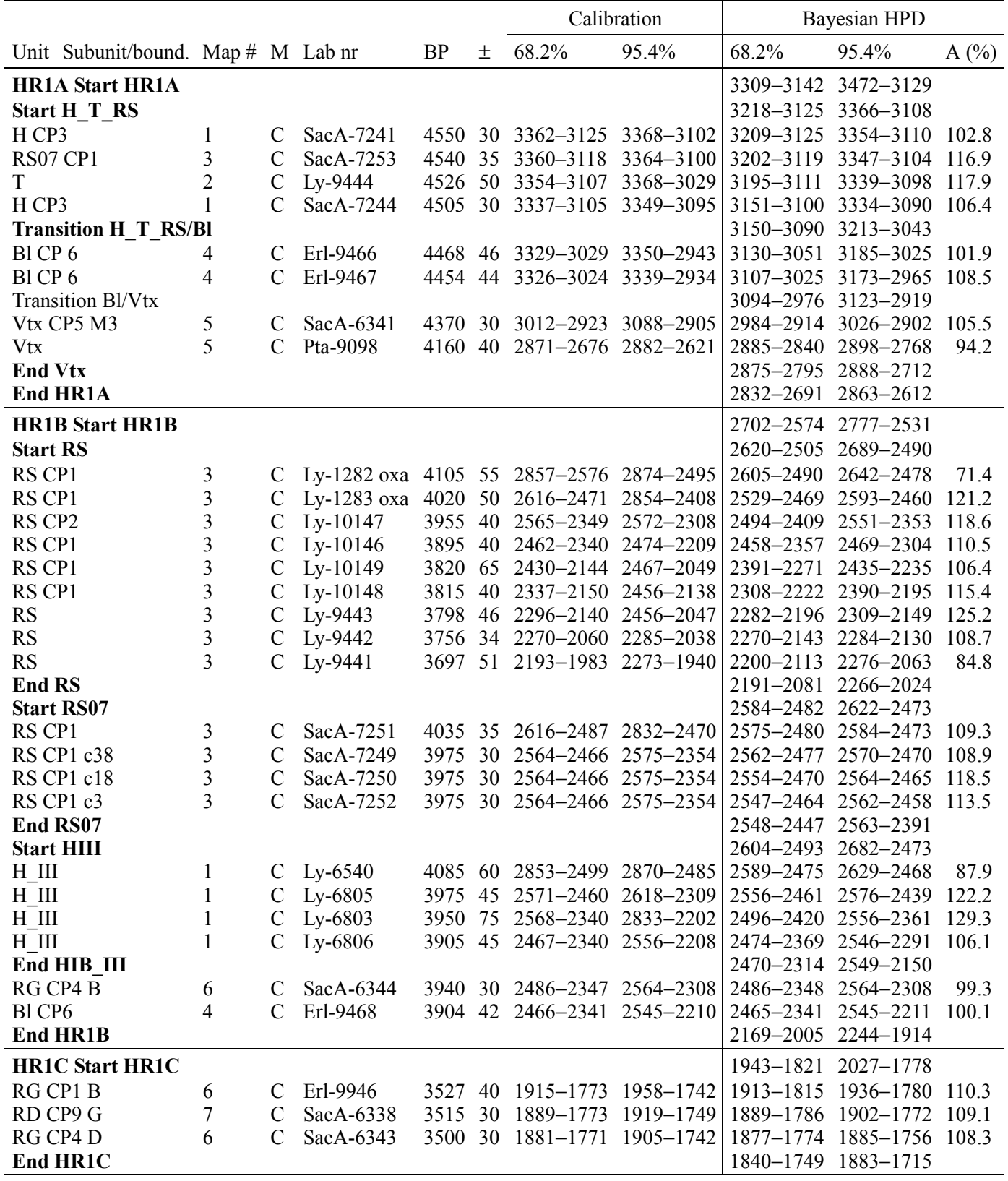

sequence for Ounjougou (Huysecom et al. 2004). In this sequence, Phases 4 and 5 constitute the Late Holocene period occupations. Phase 4 corresponds to the cultural layers of the site Ravin du Hibou, discovered in a fluvial channel context, dated to the 3 rd millennium cal BC (H; Figure 1, \#1), Table 1). Phase 5 covers the 2 nd millennium cal BC, and was established with data coming from the fluviolacustrine deposits of the Varves site (VW; Figure 1, \#7; Table 2), which are particularly 
Table 2 Chronostratigraphic and spatial attribution of the HR2 unit ${ }^{14} \mathrm{C}$ dates, with calibrations, highest posterior densities and agreement indices (A). Material (M): $\mathrm{C}=$ charcoal; $\mathrm{P}=$ Pearl millet caryopsis.

\begin{tabular}{|c|c|c|c|c|c|c|c|c|c|c|}
\hline \multirow[b]{2}{*}{ Site/unit/bound. } & \multirow[b]{2}{*}{ Map \# } & \multirow[b]{2}{*}{$\mathrm{M}$} & \multirow[b]{2}{*}{ Lab nr } & \multirow[b]{2}{*}{ BP } & \multirow[b]{2}{*}{ \pm} & \multicolumn{2}{|c|}{ Calibration } & \multicolumn{3}{|c|}{ Bayesian HPD } \\
\hline & & & & & & $68.2 \%$ & $95.4 \%$ & $68.2 \%$ & $95.4 \%$ & $\mathrm{~A}(\%)$ \\
\hline $\begin{array}{l}\text { HR2Aa Start HR2Aa } \\
\text { Start VW_2_13_RD }\end{array}$ & & & & & & & & $\begin{array}{l}1770-1676 \\
1717-1643\end{array}$ & $\begin{array}{l}1820-1640 \\
1758-1629\end{array}$ & \\
\hline VW 2 & 7 & $\mathrm{C}$ & Ly-8848 & 3420 & 40 & $1856-1664$ & $1876-1622$ & $1706-1639$ & $1738-1628$ & 102.6 \\
\hline RD $\bar{C} P 9 \mathrm{~J}$ & 7 & $\mathrm{C}$ & SacA-6336 & 3395 & 30 & $1739-1640$ & $1756-1614$ & $1694-1635$ & $1723-1623$ & 101 \\
\hline VW_6 & 7 & $\mathrm{C}$ & Ly-8136 & 3385 & 45 & $1739-1625$ & $1867-1530$ & $1688-1627$ & $1705-1607$ & 122.5 \\
\hline VW_9 & 7 & $\mathrm{C}$ & Pta-7743 & 3270 & 60 & $1619-1460$ & $1685-1430$ & $1684-1615$ & $2-1565$ & 62.5 \\
\hline VW_13 & 7 & $\mathrm{P}$ & Erl-9196 & 3416 & 109 & $1882-1608$ & 2016-1456 & $1681-1606$ & $2-1533$ & 107.9 \\
\hline VW_13 & 7 & $\mathrm{C}$ & Pta-7738 & 3240 & 60 & $1605-1440$ & $1665-1407$ & $1680-1590$ & $1690-1494$ & 58.2 \\
\hline End VW_2_13_RD & & & & & & & & $1680-1576$ & $1721-1457$ & \\
\hline $\begin{array}{l}\text { RG CP1 } \bar{F}- \\
\text { End HR2Aa }\end{array}$ & 6 & $\mathrm{C}$ & Erl-9945 & 3385 & 35 & $1736-1632$ & $1768-1535$ & $\begin{array}{l}1695-1625 \\
1671-1491\end{array}$ & $\begin{array}{l}1744-1608 \\
1687-1288\end{array}$ & 107.1 \\
\hline $\begin{array}{l}\text { HR2Ab Start HR2Ab } \\
\text { Start VW_23 }\end{array}$ & & & & & & & & $\begin{array}{l}1276-1118 \\
1235-1112\end{array}$ & $\begin{array}{l}1418-1060 \\
1316-1055\end{array}$ & \\
\hline VW_23 & 7 & $\mathrm{P}$ & Erl-9197 & 3078 & 131 & 1493-1129 & $1627-946$ & $1224-1113$ & $1284-1055$ & 90 \\
\hline VW_23b & 7 & $\mathrm{C}$ & Pta-7733 & 2920 & 60 & $1211-1020$ & $1308-932$ & 1211-1113 & -1056 & 114.5 \\
\hline VW_23d & 7 & $\mathrm{C}$ & Ly-8847 & 2985 & 40 & $1294-1129$ & $1379-1055$ & $1200-1088$ & $1244-1051$ & 82.3 \\
\hline End VW_23 & & & & & & & & $1183-1080$ & $1238-1038$ & \\
\hline Start KP $\overline{5}$ & & & & & & & & $1196-1092$ & $1258-1047$ & \\
\hline K s1_P5 & 8 & $\mathrm{C}$ & ETH-28751 & 2915 & 50 & $1206-1024$ & $1286-940$ & $1191-1083$ & $1219-1042$ & 117 \\
\hline K s6_P5 & 8 & $\mathrm{C}$ & ETH-32421 & 2915 & 50 & $1206-1024$ & 128 & 118 & 040 & 120.5 \\
\hline K s3_P5 & 8 & $\mathrm{C}$ & ETH-28753 & 2850 & 50 & $1110-930$ & $1207-896$ & $1185-1060$ & 1199-1024 & 72 \\
\hline End $\overline{\mathrm{K}} \mathrm{P} 5$ & & & & & & & & $1155-1043$ & $1195-1006$ & \\
\hline & 9 & $\mathrm{C}$ & Ly-8850 & 2905 & 40 & $1188-1015$ & $1258-977$ & 1189-1069 & $1246-1023$ & 105.7 \\
\hline End HR2Ab & & & & & & & & $1120-1011$ & 1182-971 & \\
\hline HR2B Start HR2B & & & & & & & & $1033-941$ & $1098-910$ & \\
\hline Start VW 36 & & & & & & & & $1001-929$ & & \\
\hline VW_36 & 7 & $\mathrm{C}$ & Pta- & 2800 & 60 & 102 & 112 & $992-925$ & 898 & 129.6 \\
\hline VW_37 & 7 & $\mathrm{C}$ & Ly-8846 & 2840 & 45 & $1051-922$ & $1189-859$ & $984-916$ & $1030-891$ & 107.4 \\
\hline End VW_36_37 & & & & & & & & $980-905$ & $1015-850$ & \\
\hline $\mathrm{KKN} \mathrm{CP2}$ & 10 & $\mathrm{C}$ & ETH-27716 & 2775 & 45 & $976-845$ & $1025-818$ & $987-906$ & $1013-849$ & 107.4 \\
\hline End HR2B & & & & & & & & $970-860$ & $1001-765$ & \\
\hline HR2C Start HR2C & & & & & & & & $815-659$ & $866-550$ & \\
\hline Start RG_Ro & & & & & & & & $772-548$ & 539 & \\
\hline RG CP6 F & 11 & $\mathrm{C}$ & SacA-6345 & 2510 & 30 & $767-551$ & $787-536$ & 42 & -537 & 88.7 \\
\hline RG CP13, base F & 12 & $\mathrm{C}$ & Erl- & 2473 & 36 & $751-521$ & 414 & $754-$ & 16 & 113.7 \\
\hline RON CP3 & 12 & $\mathrm{C}$ & Erl-8357 & 2440 & 44 & $734-410$ & $754-404$ & 749 & 188 & 99.5 \\
\hline RG CP9 G & 13 & $\mathrm{C}$ & SacA-6335 & 2400 & 50 & $715-398$ & $751-390$ & $747-505$ & $753-455$ & 74.2 \\
\hline End RG_Ron & & & & & & & & $746-494$ & $751-431$ & \\
\hline Start PRE_P6 & & & & & & & & $768-537$ & $791-492$ & \\
\hline PRE_P6 & 14 & $\mathrm{C}$ & Ly-1281 oxa & 2445 & 50 & $745-410$ & 405 & $756-524$ & $765-477$ & 101.6 \\
\hline PRE_P6 & 14 & $\mathrm{C}$ & Ly-1285 oxa & 2435 & 45 & $731-409$ & $753-402$ & $750-509$ & $756-452$ & 96.4 \\
\hline End PRE_P6 & & & & & & & & $747-496$ & $752-424$ & \\
\hline K s7A & & $\mathrm{C}$ & ETH-32423 & 2540 & 50 & $794-551$ & $807-426$ & $773-548$ & $791-524$ & 93 \\
\hline End HR2C & & & & & & & & $736-463$ & $747-323$ & \\
\hline
\end{tabular}

important from a diachronic point of view, because of their richness in archaeological and organic remains, included in a complex laminated deposits system. From 2002 onwards, archaeological research was extended into the colluvio-alluvial deposits located on both sides of the Yamé Valley, in order to improve the cultural resolution of the Late Holocene (Huysecom et al. 2002). Between 2002 and 2006, the excavations of 8 sectors at the Kélisogou site (K; Figure 1, \#8; Table 2) revealed, in comparison to the Varves site, a lower stratigraphical accuracy and some local bioturbation by termites, but a larger amount of artifacts, allowing us to define a more precise archaeological context for Phase 5 (Ozainne 2006). The existence of a new cultural phase (Phase 6), dated to the first half of the 1 st millennium cal BC, was also established on this site. 


\section{Chronostratigraphy, General Stratigraphy, Sample Selection, and Dating}

Due to the rapid incision into the Holocene alluvial filling after 1936, excellent exposures have been developed along the valley bottom, which gave us the opportunity to estimate the fluvial architecture of the deposits (Rasse et al. 2006; Lespez et al. 2008). Understanding the global organization of the Yamé Valley deposits was hampered by a discontinuous configuration of sedimentary sequences due to the presence of transversal sandstone bedrock outcrops. In order to reconstruct a general chronostratigraphy of the valley, the stratigraphical limits of the Holocene formations were systematically followed and sketched along an 800-m portion of the Yamé Valley through the establishment of more than 50 profiles that were cut. Two main Late Holocene subsequences (HR1 and HR2) were defined, comprising 7 units (HR1A-HR2C); those units include subunits (e.g. HIII, KP5) that consist of groups of contexts or single contexts. The first letters of subunits names correspond to their origin site code (Tables 1-2). The sections preserving maximum stratigraphic variability were selected for sampling, in order to perform particle-size, micromorphological, and ${ }^{14} \mathrm{C}$ analyses. For particle-size analysis, samples were collected in the main sedimentary lithofacies. Particle-size parameters were estimated according to Folk and Word (1957) in order to define the environmental conditions during deposition. The sections preserving maximum stratigraphic variability were also selected for micromorphological analyses. Micromorphological analyses were carried out for the detection of microbedded sediment structures and description of sedimentary facies and pedological features (humification, biological activity, micro-aggregation, hydromorphic features, oxidation and desiccation features) in order to reconstruct seasonal variations (Le Drezen et al. 2006; Le Drezen 2008). Dating analyses were performed on small charcoal samples taken from the described sedimentary units. The precise field description of the sedimentary unit completed by micromorphological analyses was also practiced to avoid sampling of layers potentially contaminated with younger charcoal resulting from pedological bioturbation, particularly due to termite activity. Sedimentation of charcoal in the Yamé Valley has 2 possible origins, either a local and seasonal production as shown by the fire-signature analysis or reworking of charcoal along the fluvial system. In order to limit the risk of dating charcoal transported along the river system, we progressively decided to choose the small elongated charcoal fragments of the fine layers corresponding to low-energy and decantation sedimentation processes, although this made accelerator mass spectrometry (AMS) ${ }^{14} \mathrm{C}$ dating necessary. Anthracological determination of the taxa before dating was useful to choose a representative sample of the local vegetation and, whenever available, charred grass stalks were used for ${ }^{14} \mathrm{C}$ dating instead of potentially long-lived woody dicots. Both strategies were applied in order to avoid the "old wood" effect. AMS dating was performed at the C14-Labor of Erlangen, Germany (Table 1-2: Erl), the ETH/PSI Ion Beam Physics laboratory of Zurich, Switzerland (Table 1-2: ETH), and the ARTEMIS installation at Saclay, France (Table 1-2: SacA). Conventional ${ }^{14} \mathrm{C}$ dates were performed at the CDRC of Lyon (Ly) and at the Quaternary Dating Research Unit of Pretoria, South Africa (Pta). Because of their small size, 2 charcoal samples coming from the archaeological sites Ravin Sud and Promontoire P6 were prepared at the CDRC of the University of Lyon1 and AMS measurements were done at Oxford (Figure 1, \#3 and 14; Table 1-2: Ly-OxA).

\section{Bayesian Analysis}

Stratigraphical and archaeological information issued from the different studies mentioned above was synthesized by elaborating a first general sequence in the shape of a Harris matrix, using the Stratify v 1.3 software (Harris 1979; Herzog 2004). This diagram was of particular significance to connect the valley and plateau sequences, as well as to summarize and check the position and relationships of every stratigraphical unit (context), and thus of every ${ }^{14} \mathrm{C}$ date. Every unit puts together several contexts or groups of contexts (subunits). Figure 2 shows the overall sequence diagram, with 
the main subdivisions and groups of contexts, as well as the number of ${ }^{14} \mathrm{C}$ dates for each context or group of contexts. The resulting sequence constituted the prior information to be incorporated in a Bayesian statistical analysis, realized with OxCal v 4.0.5 software (Bronk Ramsey 1995, 2001, 2008) and the IntCal04 atmospheric calibration curve (Reimer et al. 2004). Bayesian analysis consists of using stratigraphic information to recalculate the probability density functions for each date (Buck et al. 1991). The results are generated as posterior probability distributions, and ranges incorporating $68.2 \%, 95.4 \%$, or $99.7 \%$ of the total area of the distributions are also calculated with the highest probability density; those ranges are often referred to as a highest posterior density range (hpd). OxCal calculates individual agreement indices (A), which give a measure of the agreement between the modeled distribution and the prior likelihood for each date. When lower than $60 \%$, the date should be questioned. A model agreement index $\left(\mathrm{A}_{\text {model }}\right)$ is also calculated, allowing one to see if the whole model is acceptable (Bronk Ramsey 1995, 2001, 2008). Dates and group of dates were organized in "phases" or "sequences" in the OxCal model according to their stratigraphic relationships. Before running the model, a few more dates coming from archaeological contexts were rejected, because of their distant spatial position or delicate stratigraphic context. Bayesian analysis results for the $54{ }^{14} \mathrm{C}$ selected dates in the definitive sequence described below increase the chronological resolution, and thus a better determination of chronostratigraphical units, which constitute an efficient structure to analyze the evolution of cultural patterns and landscapes during the Late Holocene of Ounjougou. The structure of the definitive sequence (Figure 2) and some significant Bayesian analysis results are described in the Results section.

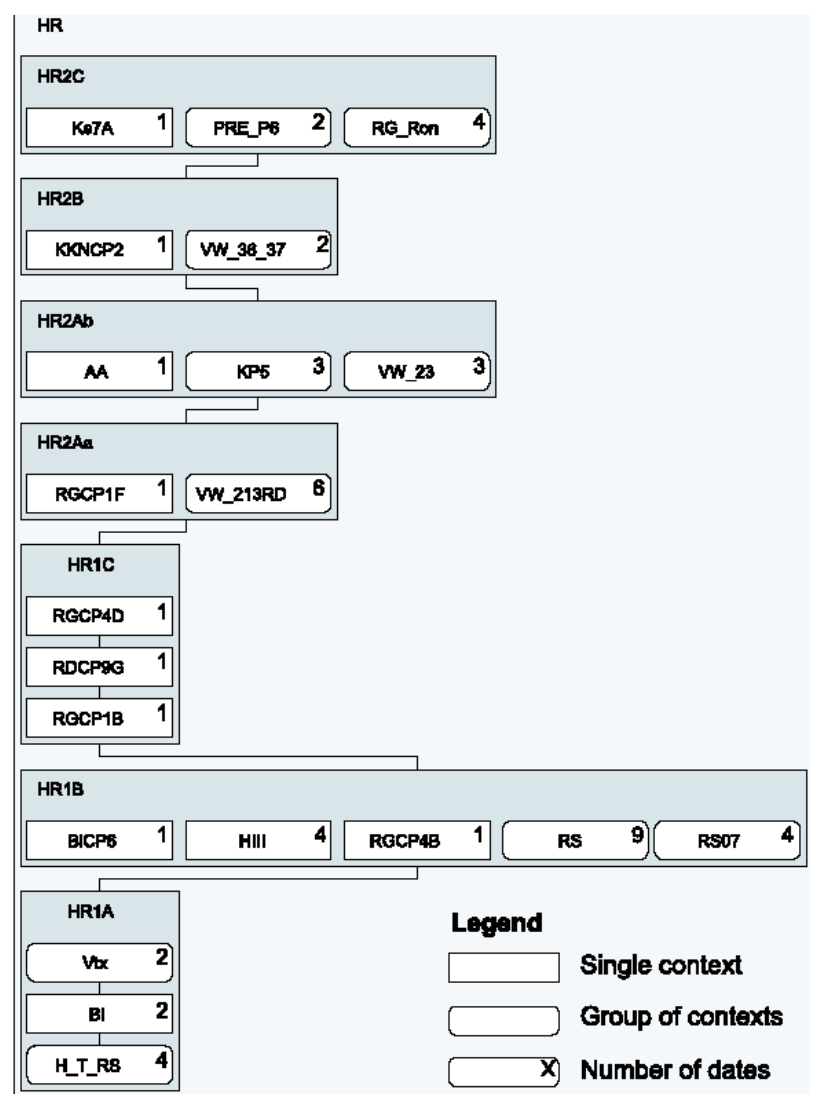

Figure 2 Harris matrix for the whole Late Holocene stratigraphic sequence of Ounjougou. 


\section{RESULTS}

The general sequence described in this section integrates stratigraphical data and data originating from the archaeological and geomorphologic studies mentioned in the Methods section. The definitive chronology is given in the Discussion chapter. In unit HR1, the valley bottom records detritic bedded alluvial formations with a high content of organic matter. They comprise middle and coarse sand layers with gravel, regularly interrupted by more complex formations of gray to black color with much organic matter either charred or not. The HR1A unit consists of a succession of 3 contiguous environmental sequences, while HR1B is composed by 3 overlapping sequences and 2 single contexts containing environmental and archaeological information (Table 1; Figure 2). HR1C consists of 1 sequence of 3 environmental single contexts (Table 1; Figure 2). The sediments of the HR2 unit lie in discordance with the previous formations. They are characterized by an alternation of silty sand layers $(1-2 \mathrm{~cm})$ rich in charcoal and organic remains (leaf remnants, seeds) and sandy silt layers becoming finer to the top, which contain numerous microcharcoal fragments. These fine layers also show desiccation cracks and oxidation horizons at their top, which are increasingly distinct between 4 to $2.4 \mathrm{kyr}$ cal BP. This rhythmic sedimentation attests a seasonal sedimentation pattern and increase of the duration and/or intensity of the dry season (Le Drézen et al. 2006; Le Drézen 2008). HR2Aa consists of a phase with 1 sequence (VW_2_13_RD), corresponding to the lower Varves site subunit, and 1 single context (Table 2; Figure 2). This phase integrates both environmental and archaeological data. The VW_2_13_RD sequence revealed a chronological inversion (Figure 3).

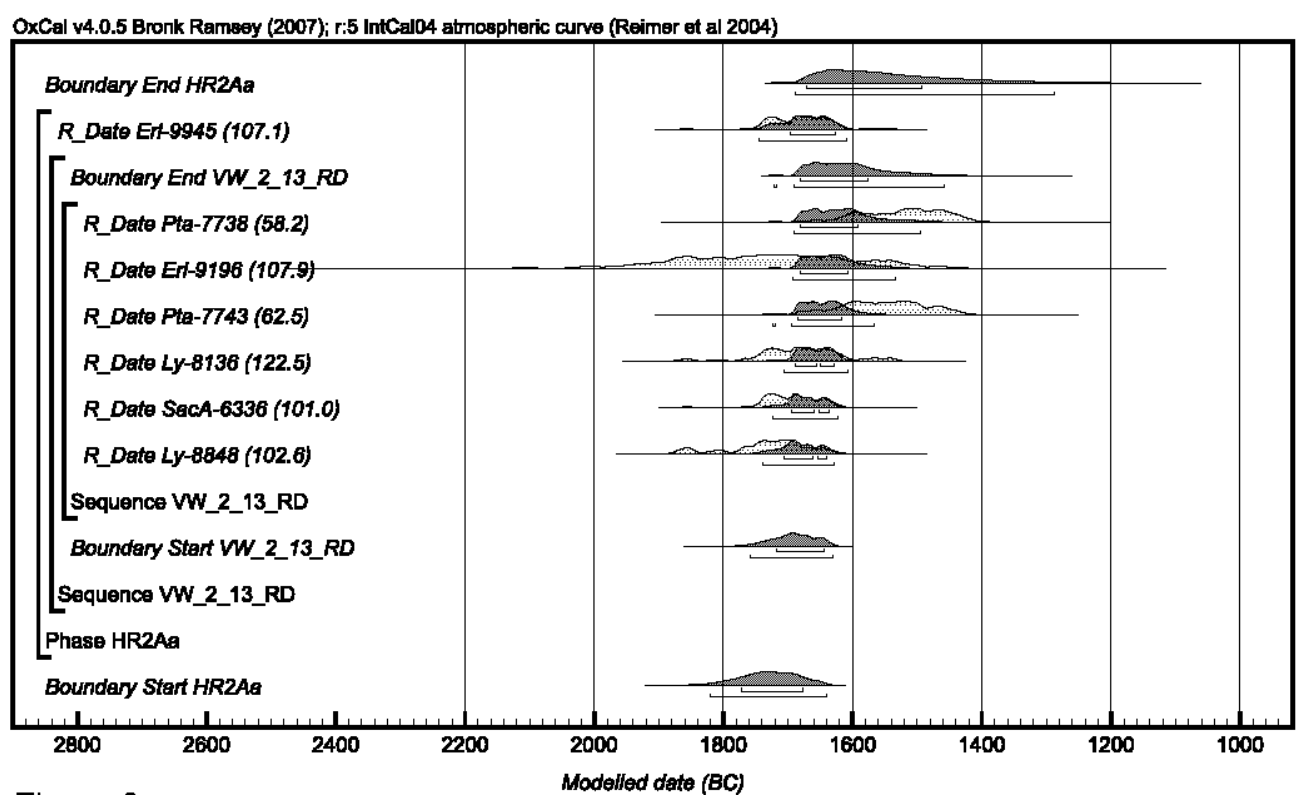

Figure 3 OxCal v 4.0.5 Bayesian model of unit HR2Aa, showing the most important chronological inversion of the sequence. The light gray histograms show the calibrations probability distributions, before Bayesian analysis. The dark gray histograms correspond to posterior distributions.

The dating of a charcoal located in layer 9 gave an age of $3270 \pm 60$ BP (Pta-7743; Table 2). This result therefore seems younger than the upper dated pearl millet caryopsis (see below), which gave an age of $3416 \pm 109 \mathrm{BP}$ (Erl-9196; Table 2). The inversion may be related to bioturbations that have not been detected during the fieldwork, the Varves site stratigraphy being particularly complex. 
Moreover, the Erl-9196 sample corresponds to a charred pearl millet caryopsis containing a low amount of carbon, resulting in a higher standard deviation of the date. However, the result for this sample obtains a good agreement index after Bayesian analysis $(\mathrm{A}=107.9 \%)$, while the underlying charcoal shows a lower but acceptable one (Pta-7743: $\mathrm{A}=62.5 \%)$. On the other hand, the agreement index of a third upper sample is insufficient (Pta-7738: $\mathrm{A}=58.2 \%$ ). This date should thus be questioned, and it seems likely that the particular complexity of the Varves site sedimentation constitutes the main part of the problem. The HR2Ab unit is of significant importance in the overall sequence because it constitutes the major connection between the valley sequence and the plateau archaeological sites sequences. The ceramic studies allowed setting up typological links between the second Varves site subunit (VW_23) and the main horizons of the Kélisogou (KP5) and AA sites. In the model, HR2Ab therefore consists of a phase of 2 overlapping sequences (VW_23 and K5) and 1 single context (AA). A minor reversal has also been observed in HR2Ab (Pta-7733, Ly-8847), at the Varves site. Despite of their inversion, the agreement indices of those dates are still significant after Bayesian analysis (Table 2). The HR2B phase was also elaborated with ceramic typological links, and includes the upper Varves site sequence (VW_3637) and a single plateau archaeological context (KKN CP2). Another minor inversion was observed in HR2B (Pta-7704, Ly-8846). Like in the previous HR2Ab case, the A indices for those 2 reversed dates are significant (Table 2; Figure 2). The upper HR2C phase consists of 2 overlapping sequences and 1 single context. Once again, archaeological information was used to link the RG_Ron sequence with the PRE_P6 one; the single context (Ks7A_P5) corresponds to the upper unit of the Kélisogou site sequence (Table 2; Figure 2). An important inversion was observed in unit HR2C. On the left bank of the Yamé River, a dated charcoal gave an age of $2641 \pm 31$ BP (Erl-9947), though located higher in the profile than a sample dated to $2440 \pm 44 \mathrm{BP}$ (Erl-8357). As its stratigraphic attribution was well determined, this date may constitute evidence for the possibility of reworking "old" charcoal along the river system. This latter date was not included in the final chronological model.

The general valley sequence therefore shows only a few chronological inversions, and the model as a whole shows a significant agreement index $\left(\mathrm{A}_{\text {model }}=126.6 \%\right)$. Nevertheless, the exceptionality of these cases underlines that the dated charcoals mainly have a local origin related with fast aggradation and important local sedimentation delivery. Charcoal particles might have been transported and redeposited along the fluvial system (soil, river bank, and bed erosion), but only within a short cycle and for a short distance. The Yamé River valley consequently shows a local production and a fast circulation of charcoal fragments during probably less than 1 century. During HR2A, the onset of agriculture in the region is revealed by finds of several caryopses of domesticated pearl millet (Pennisetum glaucum ssp. glaucum). Two of them were directly ${ }^{14} \mathrm{C}$ dated by AMS, one originating from the HR2Aa unit (Erl-9196: $3416 \pm 109$; hpd 95.4\%: 1692-1533) and one from the HR2Ab unit (Erl9197: $3078 \pm 131$; hpd 95.4\%: 1284-1055). The small amount of carbon in the small grains caused a high standard deviation, quite similar to other West African AMS-dated pearl millet finds (Kahlheber and Neumann 2007), but the stratigraphic context provided good prior information for the Bayesian analysis, despite of the inversion case mentioned above. The results also correspond well with dates from charcoal in the same units (Table 2; Figures 2-3) and show that the pearl millet was found in situ. Finally, the high amounts and the distribution of microcharcoal in the laminated sediments point to an annual occurrence of bush fires, at the beginning and at the end of the dry season.

\section{DISCUSSION: THE CHRONOCULTURAL AND ENVIRONMENTAL LATE HOLOCENE SEQUENCE OF OUNJOUGOU}

The units of the sequence described above and the Bayesian analysis results are used here to elaborate a general chronocultural and environmental sequence for the Late Holocene of Ounjougou, with 
an emphasis on the appearance of agriculture in the region. The start/end/transition boundary ranges given as chronological limits for each phase or unit correspond to the Bayesian analysis hpd ranges calculated by OxCal, in $\mathrm{BC}$ calendar ages (95.4\% confidence; Tables $1-2)$.

\section{HR1}

During HR1, the detritic bedded alluvial formations, indicating a meandering to anastomozing river system in a wooded marshland environment, can be related to the humid period recorded in West Africa until about $5 \mathrm{kyr}$ cal BP (Servant 1983; deMenocal et al. 2000; Gasse 2000; Lézine et al. 2005). It corresponds locally and more generally to the development of wetlands characterized by hygrophilous vegetation with Guinean affinities within a dense savanna including Sudanian trees (Ballouche and Neumann 1995; Salzmann et al. 2002; Waller et al. 2007). The HR1A unit (start 3472-3129 cal BC; end 2863-2612 cal BC) corresponds to the transition between the Middle/Late Holocene at Ounjougou, at the end of the 4th millennium cal BC. As evidenced by pollen (Le Drezen 2008) and charcoal analyses (Eichhorn and Le Drezen 2006; Eichhorn and Neumann, in press), it is characterized by the presence or persistence of some Sudano-Guinean tree taxa (Lophira, Parinari, Uapaca, Alchornea, Syzygium) and of African bamboo (Oxytenanthera abyssinica). The reconstructed Yamé Valley landscape consists of different types of mosaic, associating savannas, woodlands and dry forests, with gallery-forest along the river and permanent ponds. The large amounts of charcoal fragments in the deposits reveal the importance of bush fires, due to the abundance of biomass at this period. Since there is no direct archaeological data for this phase, we still have no information about technical, cultural, and economical behaviors. During HR1B (start: 2777-2531 cal BC; end: 2244-1914 cal BC), the vegetation changes indicate a gradual aridification of landscapes due to decreasing rainfall. Sudano-Guinean taxa gradually decrease and become rare in the savannas and woodlands, and persist, if at all, only in the extrazonal gallery forest (Syzygium, Alchornea, and Uapaca). Within the gallery forest, the percentage of Syzygium increases proportionally to the decrease of the other taxa. In the zonal vegetation, they are replaced by Sudanian species, and the landscape becomes a typically Sudanian savanna/woodland mosaic, with a predominance of Sapotaceae and Combretaceae. Almost certainly, climate is not the only factor responsible for vegetation change, and species like Daniellia oliveri and taxa able to resprout from suckers were indirectly supported by fire and human clearing activities.

The archaeological Phase 4 (see Methods) is included in the HIII subunit (start: 2682-2473 cal BC; end: 2549-2150 cal BC), and corresponds to the beginning of the Late Neolithic of Ounjougou. Ceramic patterns reveal clear northern cultural influences. Noteworthy are particularly large hemispherical bowls with cord-wrapped cord or large twisted string roulette covering decoration. The vessel rims are also underlined by several types of stamp impressions, including wavy patterns. These ceramics also contain, in addition to quartz temper, important concentrations of sponge spicules. Those elements indicate some migrations coming from the Saharan zones. In the Sahara, aridification caused high mobility and southward movement of populations (Kuper and Kröpelin 2006). In our case, the migrations were probably partly following the Tilemsi Valley (Smith 1974). There is no archaeological information known for the HR1C unit (start: 2027-1778 cal BC; end: 18831715 cal BC), which constitutes the end of the HR1 sequence.

\section{HR2}

During HR2, the development of a wandering river system characterized by powerful flash floods during the wet season and weakness of stream flow during the dry season is due to the increase of duration and intensity of the dry season. This can be linked with other records that testify a rise in 
aridity between 5 and $3 \mathrm{kyr}$ cal BP (deMenocal et al. 2000; Gasse 2000; Salzmann et al. 2002; Lézine et al. 2005; Waller et al. 2007; Kröpelin et al. 2008), involving the gradual movement of large vegetation zones to their current limits. Locally, the paleobiological and micromorphological studies indicate landscapes of persistent gallery forests and savannas with Sahelo-Sudanian affinities annually traversed by fires (Le Drézen et al. 2006; Le Drézen 2008; Eichhorn and Neumann, in press). In the HR2Aa and HR2Ab units, in which the archaeological Phase 5 (see Methods) is included, environmental data indicate a strong seasonality and show the coincidence of climatic deterioration and increasing human impact on the vegetation. The landscape opening trend, which was initiated during HR1, continues. Rhythmically laminated sediments indicate a strong seasonal functioning of the hydrosystem. The high amounts and the distribution of microcharcoal in the laminated sediments point to an annual occurrence of anthropogenic bush fires, at the beginning and at the end of the dry season (Le Drézen et al. 2006; Le Drézen 2008). In spite of the apparent vegetation changes, the climate was probably still more humid than at present. This is indicated by the persistence of woody species like Parinari cf. curatellifolia or Lophira lanceolata and of Oxytenanthera abyssinica, which are no longer present in the area today but only occur further to the south in zones with higher annual precipitation rates. In unit HR2Aa (start 1820-1640 cal BC; end 1687$1288 \mathrm{cal} \mathrm{BC}$ ), the onset of agriculture in the region is revealed by finds of several caryopses of domesticated pearl millet (Pennisetum glaucum ssp. glaucum). The pearl millet of Ounjougou, appearing by the 17-16th centuries BC, is contemporaneous with other earliest domesticated Pennisetum finds in West Africa (Neumann 2005; Kahlheber and Neumann 2007; Eichhorn and Neumann, in press).

During HR2Aa, the archaeological Phase 5 (see "Archaeological Investigations" section) ceramics shows a clear cultural break with the previous archaeological assemblage (Phase 4, HR1B). The beginning of Phase 5 is characterized by the appearance of globular bowls, vessels with restricted rims, as well as covering corded wrapped stick and corded wrapped cord roulette decoration. Furthermore, the first settlement structures known in the region are observed at the base of the HR2Aa unit (Huysecom et al. 2004; Ozainne et al. 2004). Unit HR2 Ab (start 1418-1060 cal BC, end 1182$971 \mathrm{cal} \mathrm{BC}$ ) can be considered as the main occupation of the valley during the Late Holocene. During this episode, corresponding to the continuation of Phase 5, the everted rim vessels rate increases, and we note the appearance of the most typical ceramic decoration of the regional Late Neolithic, characterized by parallel curved incisions on the necks of vessels (Ozainne 2006). The large amount of archaeological remains, the appearance of stone structure settlements, and the presence of grinding stones, polished axes, and polishing tools throughout the HR2Aa and HR2Ab units confirm the development of a food-producing economy in the region. The high frequency and seasonal nature of fires reveal the increasing influence of human activities on the landscape. During this period, cultivation camps and small villages are established along the Yamé Valley. Despite the fact that the nature of deposits at Ounjougou has unfortunately impeded the preservation of faunal remains, livestock breeding was most probably practiced by the 2nd millennium cal BC in the Yamé River valley. Indeed, the presence of cattle is reported at the end of the 3rd millennium cal BC in the nearby southwestern Gourma region, and by the 2nd millennium cal BC on the left side of the Niger Inland delta (MacDonald 1996; Jousse 2006). The HR2B unit (start: 1098-910 cal BC; end: 1001-765 cal BC) is a short, more humid period, with a reduction of the dry season's length. Permanent ponds appear in the valley and the landscape reveals a small increase of Sudano-Guinean taxa. The fires also decrease, showing a less important human pressure on the landscape. Up to now, the data are not adequate to interpret this phenomenon as a reduction of agricultural activities and a possible change of population size. From an archaeological point of view, this period probably coincides with the end of the important occupation shown in HR2Ab, however still with the same ceramic characteris- 
tics. Unit HR2C (start: 866-550 cal BC; end 747-323 cal BC) corresponds to the end of the Late Holocene sequence, including the archaeological Phase 6 (Ozainne 2006). This period shows a return of more arid conditions. During the dry season, which is now longer than previously thought, the ponds are entirely desiccated. Some of the Sudano-Guinean taxa finally disappear, as SudanoSahelian taxa appear. This arid episode is important and known throughout sub-Saharan West Africa. In the Yamé River valley, anthropogenic fires become important again, both at the beginning and the end of the dry season, as they were in the HR2Aa and HR2Ab units. Amazingly, there are less artifacts known for this phase; pottery characteristics seem to be comparable with those of $\mathrm{HR} 2 \mathrm{Ab}$, showing only a slight evolution of decoration techniques. The archaeological episode recorded in the HR2C unit certainly corresponds to the last phase of the regional Neolithic. The Late Holocene sequence of Ounjougou ends around $300 \mathrm{cal} \mathrm{BC}$, with the beginning of a sedimentary hiatus, which lasted until around 300 cal AD (HT1) (Le Drezen 2008; Lespez et al. 2008). This event coincides with a period of greater dryness recorded in the inner Niger delta and the majority of the African lakes around $2 \mathrm{kyr}$ cal BP (Gasse 2000; Lespez et al. 2008; Le Drezen 2008). During this phase, populations may have preferred the Bandiagara cliff (Mayor et al. 2005) and the Séno Plain areas.

\section{CONCLUSION}

The Late Holocene sequence of Ounjougou provided a large amount of chronological data linked with abundant and accurate stratigraphic prior information, allowing direct integration of archaeological and archaeobotanical information, and thus the definition of a precise cultural and environmental sequence. The results of the overall analysis allowed us to replace the previously defined cultural phases in a comprehensive geomorphological and chronostatigraphical framework, and to define a more precise chronological structure for the Dogon country Late Holocene period and main events, especially the appearance of agriculture. Considering climate reconstruction and humanenvironment relationships studies, the sedimentary records of the Yamé Valley are unique in West Africa. Indeed, they offer a new sequence for analyzing the consequences of climatic changes of various duration and intensity on the continental environment. In comparison with the lake recordings, further investigations on the rhythmic sediments of the Yamé River valley might permit a seasonal reading of climate, as well as land-use and settlement patterns. The intensity of the dry season is of particular interest, and has to be developed during the next missions of our research program. More generally, the establishment of chronostratigraphic patterns will offer the opportunity to improve the analysis of human impact on a West African river basin during the last 4 millennia. From a chronocultural point of view, the end of the Neolithic and the transition to the first protohistoric occupations in our study area remain unclear, mainly due to the HT1 sedimentary and archaeological hiatus $(300 \mathrm{cal}$ BC-cal AD 300). Since the end of the 1 st millennium $\mathrm{BC}$ is a period of great changes in the cultural, technical and environmental context in the upper Niger basin and in the whole of West Africa, it needs further investigation in Dogon country. Additional investigations in the Séno-Gondo Plain and on its margins are planned to resolve those questions.

\section{ACKNOWLEDGMENTS}

The archaeological studies were funded by the FNS (Swiss National Science Foundation), the SLSA (Swiss-Liechtenstein Foundation of Archaeological Research Abroad) and the Faculty of Science of the University of Geneva in Switzerland. The environmental studies were funded by grants (APPD Project) from the DFG (Deutsche Forschungsgemeinschaft) in Germany, the ANR (National Research Agency), and the program ECLIPSE II (INSU-CNRS) in France. Our research in Mali benefits from the support of the Cultural Mission of Bandiagara, the Institute of Human Sciences in 
Bamako, the University of Mali, the Swiss Consulate in Bamako, as well as the inhabitants of the villages of Dimmbal and Gologou. Special thanks are due to Richard Byer for improving the English text.

\section{REFERENCES}

Ballouche A, Neumann K. 1995. A new contribution to the Holocene vegetation history of the West African Sahel: pollen from Oursi, Burkina Faso and charcoal from three sites in northeast Nigeria. Vegetation History and Archaeobotany 4(1):31-9.

Bronk Ramsey C. 1995. Radiocarbon calibration and analysis of stratigraphy: the OxCal program. Radiocarbon 37(2):425-30.

Bronk Ramsey C. 2001. Development of the radiocarbon calibration program. Radiocarbon 43(2A):355-63.

Bronk Ramsey C. 2008. OxCal 4.0 manual. http:// c14.arch.ox.ac.uk/oxcalhelp/hlp_contents.html. Accessed 20 July 2008.

Buck CE, Kenworthy JB, Litton CD, Smith AFM. 1991. Combining archaeological and radiocarbon information: a Bayesian approach to calibration. Antiquity 65(249):808-21.

deMenocal P, Ortiz J, Guilderson T, Adkins J, Sarnthein M, Baker L, Yarusinsky M. 2000. Abrupt onset and termination of the African humid period: rapid climate responses to gradual insolation forcing. Quaternary Science Reviews 19(1-5):347-61.

Eichhorn B, Le Drezen Y. 2006. Les Paléoenvironnements végétaux à Ounjougou au cours de 1'Holocène. Méthodologie et résultats préliminaires. Etudes Maliennes 65:153-60.

Eichhorn B, Neumann K. In press. Holocene vegetation change and land use at Ounjougou (Mali). In: Fuller DQ, Murray MA, editors. Flora, Past Cultures and Archaeobotany in Africa. Walnut Creek, CA, USA: Left Coast Press.

Folk RL, Word WC. 1957. Brazos River Bar: a study in the significance of grain size parameters. Journal of Sedimentary Petrology 27:3-26.

Gasse F. 2000. Hydrological changes in the African tropics since the Last Glacial Maximum. Quaternary Science Reviews 19(1-5):189-211.

Granier P. 2001. Biogéographie. In: Arnaud JC, editor. Atlas du Mali. Paris: Jeune Afrique. p 22-4.

Harris EC. 1979. Principles of Archaeological Stratigraphy. New York: Academic Press.

Herzog I. 2004. Group and conquer. A method for displaying large stratigraphic data sets. In: Magistrat der Stadt Wien, Referat Kulturelles Erbe, Stadtarchäologie Wien, editors. Enter the Past. The E-Way into the Four Dimensions of Cultural Heritage. CAA 2003. BAR International Series 1227. Oxford: Archaeopress. p 423-6.

Huysecom E. 2001. The beginning of Iron metallurgy: from sporadic inventions to irreversible generalizations. In: Descoeudres J-P, Huysecom E, Serneels V,
Zimmermann J-L, editors. The Origins of Iron Metallurgy (Proceedings of the First International Colloquium on the Archaeology of Africa and the Mediterranean Basin).Mediterranean Archaeology 14:1-5.

Huysecom E. 2002. Palaeoenvironment and human population in West Africa: an international research project in Mali. Antiquity 76(292):335-6.

Huysecom E, Ballouche A, Boëda E, Cappa L, Cissé L, Dembélé A, Gallay A, Konaté D, Mayor A, Ozainne S, Raeli F, Rasse M, Robert A, Robion C, Sanogo K, Soriano S, Sow S, Stokes S. 2002. Cinquième campagne de recherches à Ounjougou (Mali). In: Jahresbericht 2001. Zürich, Vaduz: FSLA, Fondation Suisse-Liechtenstein pour les recherches archéologiques à l'étranger. p 55-113.

Huysecom E, Ozainne S, Raeli F, Ballouche A, Rasse M, Stokes S. 2004. Ounjougou (Mali): a history of Holocene settlement at the southern edge of the Sahara. Antiquity 78(301):579-93.

Huysecom E, Sanogo K. 2006. 1907-1997-2007: un siècle de travaux historiques et archéologiques en «Pays dogon», une décennie de recherche du programme «Peuplement humain et évolution paléoclimatique en Afrique de l'Ouest». Etudes Maliennes 65:5-14.

Jousse H. 2006. What is the impact of Holocene climatic changes on human societies? Analysis of West African Neolithic populations dietary customs. Quaternary International 151:63-73.

Kahlheber S, Neumann K. 2007. The development of plant cultivation in semi-arid West Africa. In: Denham T, Iriarte J, Vrydaghs L, editors. Rethinking Agriculture. Archaeological and Ethnoarchaeological Perspectives. Walnut Creek, CA, USA: Left Coast Press. p 320-46.

Killick D. 2004. What do we know about African iron working? Review essay. Journal of African Archaeology 2:97-112.

Kröpelin S, Verschuren D, Lézine A-M, Eggermont H, Cocquyt C, Francus P, Cazet J-P, Fagot M, Rumes B, Russell JM, Darius F, Conley DJ, Schuster M, Von Suchodoletz H, Engstrom DR. 2008. Climate-driven ecosystem succession in the Sahara: the past 6000 years. Science 320(5877):765-8.

Kuper R, Kröpelin S. 2006. Climate-controlled Holocene occupation in the Sahara: motor of Africa's evolution. Science 313(5788):803-7.

Le Drezen Y. 2008. Dynamiques des paysages de la vallée du Yamé depuis 4000 ans. Contribution à la compréhension d'un géosystème soudano-sahélien (Ounjougou, Pays dogon, Mali). [PhD dissertation]. Caen: University of Caen Basse Normandie. 418 p. 
Le Drezen Y, Rasse M, Ballouche A, Lespez L, Huysecom E. 2006. Dynamique d'interface Nature-Société dans un anthroposystème soudano-sahélien à l'Holocène récent (Ounjougou, Pays dogon, Mali). Actes du colloque international Interactions NatureSociété, Analyses et modèles (3-6 mai 2006, La Baule). http://letg.univ-nantes.fr/COLLOQUE/pdf/ C1_0505_LEDREZEN.pdf. Accessed 25 July 2008.

Lespez L, Rasse M, Le Drezen Y, Tribolo C, Huysecom E, Ballouche A. 2008. L'évolution hydrogéomorphologique de la vallée du Yamé (Pays Dogon, Mali): signal climatique et hydrosystème continental en Afrique de l'Ouest entre 50 et 4 ka. Géomorphologie: Relief, Processus, Environnement 3:169-85.

Lézine AM, Duplessy JC, Cazet JP. 2005. West African monsoon variability during the last deglaciation and the Holocene: evidence from fresh water algae, pollen and isotope data from core KW31, Gulf of Guinea. Palaeogeography, Palaeoclimatology, Palaeoecology 219(3-4):225-37.

MacDonald KC. 1996. The Windé Koroji complex: evidence for the peopling of the eastern inland Niger Delta (2100-500 BC). Préhistoire, Anthropologie Méditerranéennes 5:157-65.

Marshall F, Hildebrand E. 2002. Cattle before crops: the beginnings of food production in Africa. Journal of World Prehistory 16(2):99-143.

Mayor A, Huysecom E, Gallay A, Rasse M, Ballouche A. 2005. Population dynamics and paleoclimate over the past 3000 years in the Dogon Country, Mali. Journal of Anthropological Archaeology 24:25-61.

McIntosh SK. 2006. The Holocene prehistory of West Africa. In: Akyeampong EK, editor. Themes in West Africa's Prehistory. Athens: Ohio University Press. p 11-32.

McIntosh RJ, Tainter J, McIntosh SK, editors. 2000. The Way the Wind Blows: Climate, History, and Human Action. New York: Columbia University Press.

Neumann K. 2005. The romance of farming. Plant cultivation and domestication in Africa. In: Stahl AB, editor. African Archaeology. A Critical Introduction. Malden: Blackwell. p 249-75.
Nouaceur Z. 2001. Climat. In: Arnaud JC, editor. Atlas du Mali. Paris: Jeune Afrique. p 16-9.

Ozainne S. 2006. Pulsations sahariennes et premiers cultivateurs: le Néolithique récent du Plateau dogon (3500-500 av. J.-C.). Etudes Maliennes 65:69-88.

Ozainne S, Huysecom E, Ballouche A, Rasse M. 2004. Le site des Varves à Ounjougou (Mali): nouvelles données sur le peuplement néolithique des zones subsahariennes en Afrique de l'Ouest. In: Schneider J, Roost Vischer L, Péclard D, editors. Forum Suisse des Africanistes 4. Münster: LIT Verlag. p 265-81.

Rasse M, Ballouche A, Huysecom E, Tribolo C, Ozainne S, Le Drezen Y, Stokes S, Neumann K. 2006. Evolution géomorphologique, enregistrements sédimentaires et dynamiques paléoenvironnementales holocènes à Ounjougou (Plateau dogon, Mali, Afrique de l'Ouest). Quaternaire 17(1):61-74.

Reimer PJ, Baillie MGL, Bard E, Bayliss A, Beck JW, Bertrand CJH, Blackwell PG, Buck CE, Burr GS, Cutler KB, Damon PE, Edwards RL, Fairbanks RG, Friedrich M, Guilderson TP, Hogg AG, Hughen KA, Kromer B, McCormac G, Manning S, Bronk Ramsey C, Reimer RW, Remmele S, Southon JR, Stuiver M, Talamo S, Taylor FW, van der Plicht J, Weyhenmeyer CE. 2004. IntCal04 terrestrial radiocarbon age calibration, 0-26 cal kyr BP. Radiocarbon 46(3):1029-58.

Salzmann U, Hoelzmann P, Morczineck I. 2002. Late quaternary climate and vegetation of the Sudanian zone of NE-Nigeria. Quaternary Research 58(1):7383.

Servant M. 1983. Séquences continentales et variations climatiques: evolution du bassin du Tchad au Cénozoique supérieur. Travaux et Documents ORSTOM (Paris) 159:547.

Smith AB. 1974. Preliminary report of excavations at Karkarichinkiat, Mali, 1972. West African Journal of Archaeology 4:33-56.

Waller MP, Street-Perrott A, Wang H. 2007. Holocene vegetation history of the Sahel: pollen, sedimentological and geochemical data from Jikarya Lake, northeastern Nigeria. Journal of Biogeography 34(9): 1575-90. 